\title{
Yield and Quality of Ginger as Influenced by Biofertilizers, Organic and Inorganic Manures
}

\author{
G. Chandrashekhar ${ }^{1} *$ and J.K. Hore ${ }^{2}$ \\ Department of Spices and Plantation Crops, Faculty of Horticulture, \\ Bidhan Chandra Krishi Viswavidyalaya, Mohanpur, Nadia, West Bengal, 741 252, India
}

*Corresponding author

\section{Keywords}

Biofertilizers, Ginger, Growth, Inorganic fertilizers, Oleoresin, Organic fertilizers and Yield

Article Info

Accepted:

10 May 2019

Available Online:

10 June 2019

\section{A B S T R A C T}

The investigation on organic ginger (var. gorubathan) was carried out to study the effect of organic, inorganic manure and biofertilizers on ginger with reference to rhizome yield and its attributes. The study revealed that, ginger showed better response to the application of organic, inorganic and bio-fertilizer. An experiment was carried out at Horticultural Research Station, Mondouri, BCKV, West Bengal to identify the suitable bio-organic combination for production of with three types of biofertilizers namely nitrogenous biofertilizer (Azotobacter chroococcum), phosphate solubilizing Bacteria (Bacillus polymixa) and potassic mobilizer (Fraturia aurantea) with combination of inorganic fertilizer doses $(\mathrm{B} 1=\mathrm{NPK}(100 \%)+$ Azotobacter + PSB + K Mobilize B2= NPK $(75 \%)+$ Azotobacter + PSB + K Mobilizer B3 $=$ NPK (50\%) + Azotobacter + PSB + K Mobilizer and B4= Recommended NPK (100\%) and two levels of FYM i.e. $15 \mathrm{t}$ and $30 \mathrm{t}$. Among different treatments, the sole effect farmyard manure, the maximum number of primary fingers (3.69), weight of primary finger $(46.11 \mathrm{~g})$, length of primary finger $(3.88 \mathrm{~cm})$, breadth of primary fingers $(2.73 \mathrm{~cm})$, number of secondary fingers (4.57), weight of secondary finger $(167.0 \mathrm{~g})$, length of secondary finger $(9.32 \mathrm{~cm})$, breadth of primary fingers $(6.80 \mathrm{~cm})$, yield $\left(24.80 \mathrm{t} \mathrm{ha}^{-1}\right)$ and the higher oleoresin $(6.97 \%)$ content was recorded with $30 \mathrm{t} \mathrm{ha}^{-1}$, in case of inorganic and biofertilizer, maximum number of primary fingers (3.84), weight of primary fingers $(45.67 \mathrm{~g})$, length of primary fingers $(4.36 \mathrm{~cm})$, length of secondary finger $(9.09 \mathrm{~cm})$, breadth of secondary finger $(6.61 \mathrm{~cm})$, yield $(26.43 \mathrm{t}$ $\mathrm{ha}^{-1}$ ) and oleoresin (6.86) content was observed with combination of $\mathrm{B}_{1}$ (NPK $100 \%+$ Azotobacter + PSB + K mobilizer).

\section{Introduction}

Ginger (Zingiber officinale Rosc.) belongs to the family Zingiberaceae, has been prized for its aroma flavour, pungency and medicinal properties since ancient times. Among the major spices grown in the country, ginger occupied an important place, as it is a valuable source of foreign exchange. Oleoresin and essential oil of ginger are its important value added products and export of these products is increasing year after year. The refreshing aroma and the pungent taste make ginger an essential ingredient of food 
and also in food processing industries worldwide. Ginger is a long growing crop and needs a balanced supply of nutrients for higher fresh rhizome yield with a better quality, which can be supplied by organic sources. Inadequate or imbalanced nutrient supply is one of the major constraints in harvesting higher fresh rhizome yields. Large scale use of chemical fertilizers has resulted in deterioration of soil health in terms of physical, chemical and biological parameters and is also associated with other problems like nutrient loss through leaching, volatilization and dentrification of nitrogen and fixation of phosphorus. Thus, there is an emergent need to utilize other source of plant nutrients like-organic manures and vermicompost, as they constitute dependable sources of plant nutrients. The judicious use of chemical, organic and biological sources of plant nutrients and their efficient management have shown promising results not only in sustaining productivity and soil health but also in meeting a part of the chemical fertilizer requirement of crop. Biofertilizers have now emerged as a promising component of nutrient supply (Ghosh et al., 2001; Singh 2002). The role of different biofertilizers like Azospirillum and Azotobacter cultures in fixing atmospheric nitrogen has been well established by several workers (Chandrashekhar, 2003; Indiresh et al., 2003). Integrated plant nutrient system involving a combination of fertilizers, organic manures and biofertilizers are essential to sustain crop production, preserve soil health and biodiversity.

\section{Materials and Methods}

The experiment was carried out at Horticultural Research Station, Mandouri, Bidhan Chandra Krishi Viswavidyalaya, Nadia, West Bengal during 2016 and 2017 with the variety Gorubathan and spacing is $25 \times 20 \mathrm{~cm}$. The treatment details were followed as main plot applied two different doses of FYM(F1=15 tha $\mathrm{ha}^{-1}$ and F2=30 $\left.\mathrm{t} \mathrm{ha}^{-1}\right)$ and in sub-plot different Bio fertilizers along with inorganic fertilizers with different doses $(\mathrm{B} 1=\mathrm{NPK}(100 \%)+$ Azotobacter $+\mathrm{PSB}+\mathrm{K}$ Mobilize B2= NPK (75\%) + Azotobacter + $\mathrm{PSB}+\mathrm{K}$ Mobilizer B3= NPK $(50 \%)+$ Azotobacter + PSB + K Mobilizer and B4= Recommended NPK (100\%). Biofertilizers were collected from Nodule Research Laboratory, BCKV, Mohanpur.In the experiment ginger was fertilised @ 200:75:100 kg NPK ha ${ }^{-1}$ (Dey, 2011) and as per the treatment combination two levels of farmyard manure i.e. $15 \mathrm{t} \mathrm{ha}^{-1}$ and $30 \mathrm{t} \mathrm{ha}^{-1}$ were applied during land preparation. Three biofertilizers namely (Azotobacter chroococcum, phosphate solubilizing bacteria (Bacillus polymixa) and Potassic mobilizer (Fraturia aurantia) each @ 20 kg ha ${ }^{-1}$ was applied. the fertilizers were also applied in three split but started 15 days after the application of biofertilizer and interval between the splits was same. Urea, single super phosphate and muriate of potash were used as inorganic source of $\mathrm{N}, \mathrm{P}$ and $\mathrm{K}$ respectively. Observations on different growth (at 180 days after planting) and yield attributing parameters per replication.

\section{Results and Discussion}

The experimental results (pooled data) presented in Table 1 revealed that the details of primary finger number, weight, length, breadth, secondary finger number, weight, length, breadth, project yield and oleoresin contents were recorded with various treatment combination.Among the sole effect of farmyard manure, the maximum number of primary fingers (3.69) was recorded in $\mathrm{F}_{2}$ (30t $\left.\mathrm{ha}^{-1}\right)$ and $\mathrm{F}_{1}\left(15 \mathrm{t} \mathrm{ha} \mathrm{h}^{-1}\right)$ recorded minimum number of primary finger (3.18). In case of inorganic and biofertilizer, maximum number (3.84) and minimum number (3.16) were associated with $\mathrm{B}_{1}$ (NPK $100 \%+$ Azotobacter 
$+\mathrm{PSB}+\mathrm{K}$ mobilizer) and $\mathrm{B}_{4}(\mathrm{NPK} 100 \%)$, the maximum weight of primary finger 46.11 $\mathrm{g}$ was recorded under $\mathrm{F}_{2}\left(30 \mathrm{t} \mathrm{ha} \mathrm{h}^{-1}\right)$ and minimum $(37.71 \mathrm{~g})$ in $\mathrm{F}_{1}\left(15 \mathrm{t} \mathrm{ha} \mathrm{a}^{-1}\right)$. In case of inorganic and biofertilizer, $\mathrm{B}_{1}$ (NPK $100 \%+$ Azotobacter $+\mathrm{PSB}+\mathrm{K}$ mobilizer) recorded maximum weight $(45.67 \mathrm{~g}), \mathrm{B}_{4}$ (NPK 100\%) recorded minimum weight $(37.21 \mathrm{~g})$, in the sole effect of farmyard manure, the maximum $(3.88 \mathrm{~cm})$ and minimum (3.58) length of primary finger were noticed in plants treated with $\mathrm{F}_{2} \quad\left(30 \mathrm{t} \mathrm{ha}^{-1}\right)$ and $\mathrm{F}_{1} \quad\left(15 \mathrm{t} \mathrm{ha}^{-1}\right)$ respectively.

In case of inorganic and biofertilizer, maximum length of $4.36 \mathrm{~cm}$ recorded under $\mathrm{B}_{1}$ (NPK $100 \%$ + Azotobacter+ PSB $+\mathrm{K}$ mobilizer) and minimum $(3.14 \mathrm{~cm})$ recorded under $\mathrm{B}_{3}$ (NPK 50\%+ Azotobacter+ PSB+ K mobilizer), the sole effect of farmyard manure, the maximum $(2.73 \mathrm{~cm})$ and minimum $(2.44 \mathrm{~cm})$ breadth of primary fingers were observed with $\mathrm{F}_{2}\left(30 \mathrm{tha}^{-1}\right)$ and $\mathrm{F}_{1}\left(15 \mathrm{t} \mathrm{ha} \mathrm{h}^{-1}\right)$ respectively. In respect of inorganic and biofertilizer the maximum breadth of primary finger $(2.76 \mathrm{~cm})$ was associated with $\mathrm{B}_{2}$ (NPK $75 \%+$ Azotobacter+ $\mathrm{PSB}+\mathrm{K}$ mobilizer) and minimum breadth of $2.41 \mathrm{~cm}$ under $\mathrm{B}_{3}$ (NPK $50 \%+$ Azotobacter+ $\mathrm{PSB}+\mathrm{K}$ mobilizer), the sole effect farmyard manure, the maximum number of secondary fingers (4.57) was recorded with $\mathrm{F}_{2}\left(30 \mathrm{t} \mathrm{ha}^{-1}\right)$ and $\mathrm{F}_{1}\left(15 \mathrm{tha}^{-1}\right)$ recorded minimum number of 3.68 .

In case of inorganic and biofertilizer, maximum number of secondary finger (4.54) and minimum number (3.77) were associated with $\mathrm{B}_{2}$ (NPK 75\% + Azotobacter $+\mathrm{PSB}+\mathrm{K}$ mobilizer) and $\mathrm{B}_{3}$ (NPK $50 \%+$ Azotobacter + $\mathrm{PSB}+\mathrm{K}$ mobilizer), the maximum weight of secondary finger (167.0) $\mathrm{g}$ was recorded under $\mathrm{F}_{2}\left(30 \mathrm{t} \mathrm{ha}^{-1}\right)$ and minimum (138.39 g) was observed in $\mathrm{F}_{1}\left(15 \mathrm{t} \mathrm{ha}^{-1}\right)$. In case of inorganic and biofertilizer, $\mathrm{B}_{2}$ (NPK $75 \%+$ Azotobacter $+\mathrm{PSB}+\mathrm{K}$ mobilizer) recorded maximum weight (179.55 g) but $\mathrm{B}_{3}$ (NPK $50 \%+$ Azotobacter $+\mathrm{PSB}+\mathrm{K}$ mobilizer) recorded minimum weight $(115.62 \mathrm{~g})$, the sole effect of FYM, the maximum $(9.32 \mathrm{~cm})$ and minimum $(7.54 \mathrm{~cm})$ length of secondary finger were noticed in plants treated with $\mathrm{F}_{2}$ (30t ha $\mathrm{ha}^{-1}$ ) and $\mathrm{F}_{1}\left(15 \mathrm{t} \mathrm{ha}{ }^{-1}\right)$ respectively. In case of inorganic and biofertilizer, maximum length of $9.09 \mathrm{~cm}$ was recorded under $\mathrm{B}_{1}$ (NPK $100 \%+$ Azotobacter $+\mathrm{PSB}+\mathrm{K}$ mobilizer) and minimum of $7.81 \mathrm{~cm}$ was recorded under $\mathrm{B}_{3}$ (NPK $50 \%+$ Azotobacter $+\mathrm{PSB}+\mathrm{K}$ mobilizer), the sole effect of farmyard manure, the maximum $(6.80 \mathrm{~cm})$ and minimum $(5.89 \mathrm{~cm})$ breadth of primary fingers were observed with $\mathrm{F}_{2}\left(30 \mathrm{tha}^{-1}\right)$ and $\mathrm{F}_{1}\left(15 \mathrm{t} \mathrm{ha} \mathrm{h}^{-1}\right)$ respectively.

In respect of inorganic and biofertilizer the maximum breadth of primary finger $(6.61 \mathrm{~cm})$ was associated with $\mathrm{B}_{1}$ (NPK $100 \%+$ Azotobacter $+\mathrm{PSB}+\mathrm{K}$ mobilizer) and minimum breadth of $6.18 \mathrm{~cm}$ under $\mathrm{B}_{4}$ (NPK $100 \%)$. In case of sole effect of farmyard manure the maximum $\left(24.80 \mathrm{t} \mathrm{ha}^{-1}\right)$ and minimum $\left(21.62 \mathrm{t} \mathrm{ha}^{-1}\right)$ were associated with $\mathrm{F}_{2}\left(30 \mathrm{t} \mathrm{ha} \mathrm{a}^{-1)}\right.$ and $\mathrm{F}_{1}\left(15 \mathrm{tha} \mathrm{ha}^{-1}\right)$ respectively. The plants raised under inorganic and biofertilizer treatment, the maximum yield of $26.43 \mathrm{t} \mathrm{ha}^{-1}$ was observed under $\mathrm{B}_{1}$ (NPK $100 \%+$ Azotobacter $+\mathrm{PSB}+\mathrm{K}$ mobilizer) and $\mathrm{B}_{3}$ (NPK $50 \%+$ Azotobacter $+\mathrm{PSB}+\mathrm{K}$ mobilizer) recorded minimum yield $(20.21 \mathrm{t}$ $\left.\mathrm{ha}^{-1}\right)$. These findings are in good conformity with the findings of Poinkare et al., (2006) who also observed the better vegetative growth and yield with FYM + 100\% RDF + Azotobacter + PSB in turmeric. Dashet al., (2008) also recorded highest ginger yield with $100 \%$ NPK (inorganic) along with Azospirillum and FYM with highest quality and least rhizome rot incidence. In respect of level of FYM, the yield and quality of ginger increased with the increase of dose from $15 \mathrm{t}$ $\mathrm{ha}^{-1}$ to $30 \mathrm{t} \mathrm{ha}^{-1}$. The similar results also obtained by Jana et al., (2017). 
Table.1 Effect of biofertilizers, organic and inorganic manures on yield and quality of ginger

\begin{tabular}{|c|c|c|c|c|c|c|c|c|c|c|}
\hline \multirow[t]{2}{*}{ Treatment } & \multicolumn{4}{|c|}{ Primary finger } & \multicolumn{4}{|c|}{ Secondary finger } & \multirow{2}{*}{$\begin{array}{l}\text { Projected } \\
\text { yield (t ha } \\
\left.1^{-}\right)\end{array}$} & \multirow{2}{*}{$\begin{array}{c}\text { Oleoresin } \\
\text { percentage }\end{array}$} \\
\hline & Number & $\begin{array}{l}\text { Weight } \\
\text { (g) }\end{array}$ & $\begin{array}{l}\text { Length } \\
\text { (cm) }\end{array}$ & $\begin{array}{c}\text { Breadth } \\
(\mathrm{cm})\end{array}$ & Number & $\begin{array}{c}\text { Weight } \\
\text { (g) }\end{array}$ & $\begin{array}{l}\text { Length } \\
\text { (cm) }\end{array}$ & $\begin{array}{c}\text { Breadth } \\
(\mathrm{cm})\end{array}$ & & \\
\hline \multicolumn{11}{|c|}{ Farm yard manure } \\
\hline$F_{1}(15 t / h a)$ & 3.18 & 37.71 & 3.58 & 2.44 & 3.68 & 138.39 & 7.54 & 5.89 & 21.62 & 6.16 \\
\hline$F_{2}(30 t / h a)$ & 3.69 & 46.11 & 3.88 & 2.73 & 4.57 & 167.00 & 9.32 & 6.80 & 24.80 & 6.97 \\
\hline S.Em. $( \pm)$ & 0.004 & 0.043 & 0.003 & 0.002 & 0.005 & 0.253 & 0.009 & 0.005 & 0.020 & 0.024 \\
\hline C.D. $(P=0.05)$ & 0.016 & 0.168 & 0.011 & 0.008 & 0.018 & 0.993 & 0.036 & 0.018 & 0.079 & 0.071 \\
\hline \multicolumn{11}{|c|}{ Inorganic fertilizer and biofertilizer } \\
\hline $\mathbf{B}_{1}$ & 3.84 & 45.67 & 4.36 & 2.69 & 4.31 & 171.41 & 9.09 & 6.61 & 26.43 & 6.86 \\
\hline $\mathbf{B}_{2}$ & 3.29 & 42.81 & 4.00 & 2.76 & 4.54 & 179.55 & 8.69 & 6.29 & 24.04 & 6.60 \\
\hline $\mathbf{B}_{3}$ & 3.46 & 37.21 & 3.14 & 2.41 & 3.77 & 115.62 & 7.81 & 6.32 & 20.21 & 6.59 \\
\hline $\mathbf{B}_{4}$ & 3.16 & 41.94 & 3.43 & 2.49 & 3.90 & 144.19 & 8.14 & 6.18 & 22.18 & 6.21 \\
\hline S.Em. $( \pm)$ & 0.026 & 0.328 & 0.031 & 0.020 & 0.031 & 1.176 & 0.065 & 0.048 & 0.176 & 0.059 \\
\hline C.D. $(P=0.05)$ & 0.075 & 0.958 & 0.091 & 0.058 & 0.090 & 3.433 & 0.190 & 0.139 & 0.513 & 0.212 \\
\hline
\end{tabular}

Main Plot - F1 (15t/ha), F2 (30t/ha) Sub-plot - B1= NPK (100\%) + Azotobacter + PSB + K Mobilizer, B2= NPK (75\%) + Azotobacter + PSB + K Mobilizer, B3 $=$ NPK $(50 \%)+$ Azotobacter+ PSB + K Mobilizer and B4= Recommended NPK $(100 \%)$ 
They observed that increased dose of FYM has increased the rhizome yield, dry recovery and curcumin content in rhizome. As per sole effect of FYM, the higher oleoresin $(6.97 \%)$ content was recorded with $30 \mathrm{t} \mathrm{ha}^{-1}$ as compared to FYM @ $15 \mathrm{t} \mathrm{ha}^{-1}(6.16 \%)$ as per sole effect of inorganic fertilizer and biofertilizer, the oleoresin content decreased from 6.86 to 6.21 with $\mathrm{B}_{1}$ to $\mathrm{B}_{4}$. The results indicated that oleoresin content increased due to combined application bio inoculants along with $100 \%$ NPK (inorganic). It also exhibited that oleoresin content decreased with the decreasing level of inorganic NPK i.e. $6.86 \%$ to $6.59 \%$ with reduction of NPK from $100 \%$ to $50 \%$.The biofertilizer treatments improved the rhizome quality by increasing the oleoresin content in rhizome. Azotobacter, apart from their ability to fix $\mathrm{N}$, produce anti-fungal antibodies that inhibit the growth of several pathogenic fungi in the root region and hence improving root growth and crop nutrition that ultimately improves the quality of the product (Subba Rao, 2001).

\section{Acknowledgement}

The author would like to thank Dr. Jitesh Kumar Hore, Professor, Department of Plantation, Spices and Medicinal and Aromatic Crops, Faculty of Horticulture, Bidhan Chandra Krishi Viswavidyalaya for their kind help and guidance.

\section{References}

Chandrashekhar, B.S. (2003). Studies on mineral phosphate solubilizing fungi from vertisol of Northern Karnataka and other biofertilizer potential. Ph.D. Thesis, Univ. Agric. Sci., Dharwad, Karnataka.

Dash, D. K., Mishra, N.C. and Sahoo, B. K.
(2008). Influence of nitrogen, Azospirillum sp. and farm yard manure on the yield, rhizome rot and quality of ginger (Zingiber officinale Rosc.). $J$. Spices Arom. Crops, 17 (2): 177-79.

Dey. R (2011). Intercropping ginger with spacing and fertilizer response in young arecanut planation. Faculty of Horticulture. M.Sc. Thesis. BCKV.

Ghosh, D.C., Das, A.K. and Mookherjee, S.(2001). Effect of biofertilizer and growth regulator on growth and productivity of wheat at different fertility levels. Bangladesh J. Agril. Res., 26: 48795.

Indiresh, K.M., Sreekamulu, K.R and Pati, S.(2003). Response of potato to biofertilizers at graded level of chemical fertilizer. J. Indian Potato Assoc., 30:7980.

Jana, J. C., Datta, S., Bhaisare, P. T. and Thapa, A. (2017). Effect of organic, inorganic source of nutrients and Azospirillum on yield and quality of turmeric (Curcuma longa L.). Int. J. Curr. Microbio. Appl. Sci., 6 (2): 966-70.

Poinkar, M. S., Shembekar, R. Z., Chopde, N., Bhaladhare, N., Khewale, A. and Dong arkar, K. (2006). Effect of organic manure and bio fertilizers on growth and yield of turmeric (Curcuma longa L). J. Soil Crops, 16(12): 417-20.

Singh, K. (2002). Role of biofertilizers in increasing the efficiency of nitrogen to potato crop under Northeastern hilly condition. Indian Potato Assoc., 2: 90407.

Subba Rao, N.S., An appraisal of biofertilizers in India, In: S. Kannaiyan (Ed.), The Biotechnology of Biofertilizers, Narosa Publishing House, New Delhi, 2001: 45105.

\section{How to cite this article:}

Chandrashekhar, G. and Hore, J.K. 2019. Yield and Quality of Ginger as Influenced by Biofertilizers, Organic and Inorganic Manures. Int.J.Curr.Microbiol.App.Sci. 8(06): 968-972. doi: https://doi.org/10.20546/ijcmas.2019.806.117 